\title{
Epidemiology in inflammatory bowel disease: Unanswered questions - European perspective
}

VIBEKE BINDER, MD, DRMEDSCI

\begin{abstract}
V BINDER. Epidemiology in inflammatory bowel disease: Unanswered questions - European perspective. Can J Gastroenterol 1993; 7(2):139-141. Several European epidemiological studies have shown similar patterns for Crohn's disease, demonstrating an increase in incidence over the past 30 years. It has, however, not been revealed whether the apparent differences in incidence, with a much higher value in the north than in the south of Europe, are real. A European multicentre study, comprising 20 centres, is being carried out over the next three years, using well defined and equal diagnostic criteria. From published epidemiological studies, it appears that the disease entities for ulcerative colitis and Crohn's disease have remained practically unchanged during the past two decades, as regards clinical appearance at diagnosis. The different pattern in incidence of ulcerative colitis (almost steady) and Crohn's disease (steep increase) supports the concept of two different diseases. The steep increase in occurrence of Crohn's disease points to an external factor in the etiology of the disease.
\end{abstract}

Key Words: Crohn's disease, Epidemiology, Europe, Incidence, Inflammatory bowel disease

\section{Questions épidémiologiques en suspens au sujet de la maladie intestinale inflammatoire : perspective européenne}

RÉSUMÉ: Plusieurs études épidémiologiques européennes ont démontré des modèles semblables à l'égard de la maladie de Crohn, révélant du même coup une augmentation de son incidence au cours des 30 années écoulées. Les variations apparentes au plan de la fréquence entre le Nord de l'Europe (où elle serait plus répandue) et le Sud de l'Europe n'ont cependant pas encore été confirmées. Une étude multicentrique européenne comprenant 20 centres est en cours pour les trois années à venir à l'aide de critères diagnostiques uniformisés. A partir des études épidémiologiques publiées, il semble que les cas de colite ulcéreuse et de maladie de Crohn sont pour ainsi dire demeurés inchangés au cours des deux dernières décennies pour ce qui est de l'aspect clinique au moment du diagnostic. Le mode d'incidence différent de la colite ulcéreuse (presque constant) et de la maladie de Crohn (augmentation nette) appuie la thèse de deux entités cliniques distinctes. L'augmentation nette des cas de maladie de Crohn suppose la participation d'un facteur exogène dans l'étiologie de la maladie.

Department of Medical Gastroenterology C, Herlev Hospital/University of Copenhagen, Herlev, Denmark

Correspondence: DrV Binder, Herlev Hospital/University of Copenhagen, Department of Medical Gastroenterology C, Herlev Ringvej 75, DK-2730 Herlev, Denmark
THE INCIDENCE OF CROHN'S DIS-

1 ease has increased in almost all European countries during the past 20 to 30 years. The increase has been almost parallel in different studies, but displaced in time. Over the past 10 years a few studies have shown that the incidence of Crohn's disease is beginning to level off. For example, two recent studies from Sweden $(1,2)$ have shown a stable incidence, but at a very high level of about six per 100,000 population.

The pattern over time is less clear for ulcerative colitis, some studies showing an increase in incidence, with the majority indicating an almost stable incidence over the past 20 years. In Europe a correlation has been found in different places between the frequencies of the two diseases, with a 1:2 ratio of occurrence of Crohn's disease to ulcerative colitis. It appears that the highest incidence rates are in Norway $(3,4)$ and Sweden (1), followed by Denmark $(5,6)$, then Holland $(7,8)$ and finally Italy $(9,10)$ (Figure 1).

A hypothetical north-south axis has been proposed for inflammatory bowel disease (IBD), with the highest incidence in northern Europe and lowest in the south. This hypothesis is supported by the existing incidence data. The basis for epidemiological studies is a complete and totally regional group of patients, which implies that the organization of the health care system in the area studied is of importance. In 


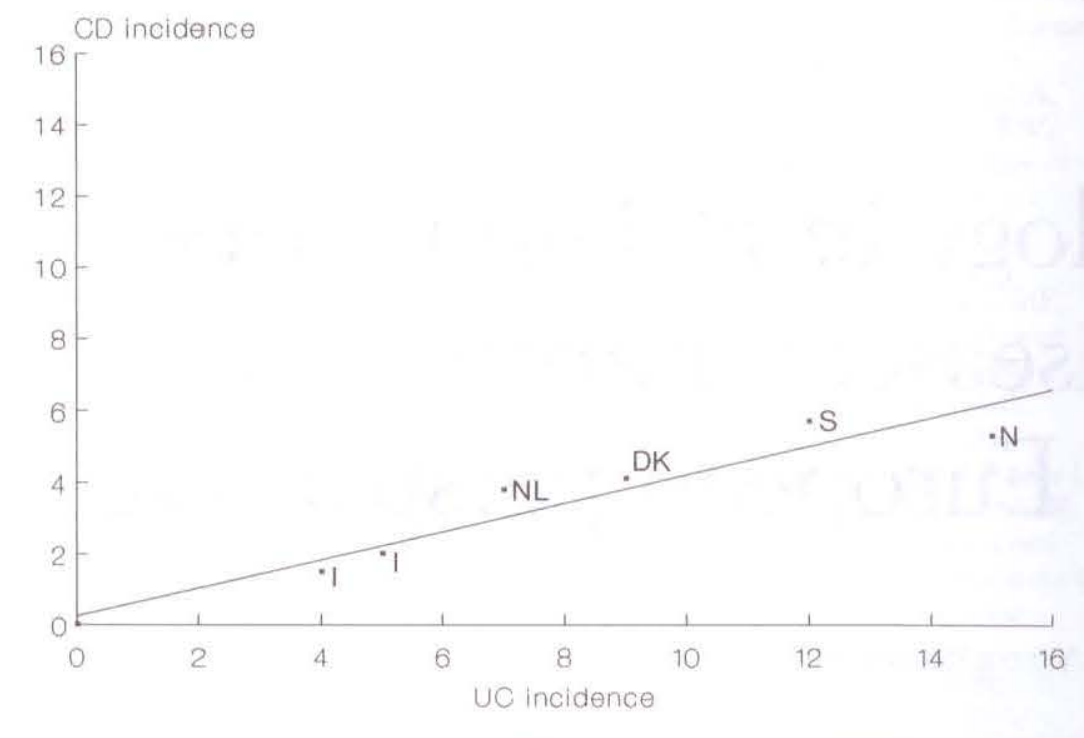

Figure 1) Correlation between incidence of ulcerative colitis and Crohn's disease

TABLE 1

Clinical data from five European studies on ulcerative colitis

\begin{tabular}{lccccc}
\hline Country & $\begin{array}{c}\text { Total } \\
(\%)\end{array}$ & $\begin{array}{c}\text { Substantial } \\
(\%)\end{array}$ & $\begin{array}{c}\text { Distal } \\
(\%)\end{array}$ & $\begin{array}{c}\text { Female:male } \\
\text { ratio }\end{array}$ & $\begin{array}{c}\text { Incidence } \\
\text { (per 100,000 } \\
\text { population) }\end{array}$ \\
\hline Italy $(9,10)$ & - & - & - & $0.7: 1$ & 4.0 \\
Netherlands $(7,8)$ & - & - & - & $1: 1$ & 6.8 \\
Denmark $(5,6)$ & 18 & 38 & 44 & $1.1: 1$ & 9.1 \\
Sweden $(1,2)$ & 30 & 28 & 42 & $0.8: 1$ & 12.0 \\
Norway $(3,4)$ & 16 & 49 & 35 & $0.9: 1$ & 14.8 \\
\hline
\end{tabular}

TABLE 2

Clinical data from six European studies on Crohn's disease

\begin{tabular}{lccccc}
\hline Country & $\begin{array}{c}\text { Ileocolic } \\
(\%)\end{array}$ & $\begin{array}{c}\text { Colon } \\
(\%)\end{array}$ & $\begin{array}{c}\text { leum } \\
(\%)\end{array}$ & $\begin{array}{c}\text { Female:male } \\
\text { ratio }\end{array}$ & $\begin{array}{c}\text { Incidence } \\
\text { (per 100,000 } \\
\text { population) }\end{array}$ \\
\hline Italy $(9,10)$ & - & - & - & $0.9: 1$ & 1.5 \\
Netherlands (7,8) & - & - & - & $1: 1$ & 3.9 \\
United Kingdom (11) & 13 & 29 & 45 & $1: 1$ & 8.3 \\
Denmark (5,6) & 33 & 30 & 29 & $1.4: 1$ & 4.1 \\
Sweden (1.2) & 27 & 28 & 42 & $1.1: 1$ & 6.1 \\
Norway (3,4) & 32 & 20 & 48 & $1.1: 1$ & 4.9 \\
\hline
\end{tabular}

southern Europe, the conditions are not optimal for such studies, since patients can choose doctors and specialists freely within and outside the country. This has hitherto made epidemiological studies difficult in these areas. However, a major initiative has been undertaken by the European Community during the past four years, culminating in the launch in October 1991 of a three-year prospective study of the simultaneous incidence of IBD in 20 different areas in Europe. The participating centres meet regularly to discuss diagnostic strategies, with a view to ensuring that the diagnostic criteria are uniform throughout the study area.

The results of this study will show whether the hitherto reported differences in occurrence of IBD in north and south Europe are real or whether they merely reflect differences in diagnostic threshold and/or referral of patients. The study should also reveal whether the characteristics of the disease differ from country to country, with respect to severity, extent of disease and other clinical paramaters.

All the European studies show a similar age pattern for IBD. In both ulcerative colitis and Crohn's disease, $50 \%$ of patients are less than 35 years old when first diagnosed. The incidence in the age group 20 to 29 years is about twice that of all other age groups. Regarding sex distribution, ulcerative colitis seems to affect both sexes almost equally. However, Crohn's disease has been found in some studies to be more frequent in women, although other studies have shown the disease to be distributed evenly between the sexes.

In a population-based study from Copenhagen county, carried out over 26 years $(5,6)$, an increase in the incidence of Crohn's disease from less than one per 100,000 inhabitants to about four per 100,000 inhabitants, was found, with a constant female:male ratio of $1.4: 1$. The incidence of ulcerative colitis was higher in women in the early part of the study period, and has been equal in the 1970s and ' $80 \mathrm{~s}$. The mean incidence was 8.1 per 100,000 .

The clinical data from five recent publications from Florence, Leyden, Copenhagen, Uppsala and western Norway are shown in Table 1. It appears that, in the Scandinavian countries, about $40 \%$ of the patients have proctosigmoiditis at diagnosis. The risk of proximal progression of the disease has been studied, and the results from Scotland (11) and preliminary results from the author's study (unpublished data) are in accordance. In the first year after diagnosis, $12 \%$ of the cases progressed proximally, and during the following 10 years a steady rate of $6 \%$ per year had more extensive disease. In half of the patients the progression occurred as far as the splenic flexure, in a quarter to the hepatic flexure and in the remainder to the cecum.

These findings strongly support the 
view that proctitis is not a separate disease entity from ulcerative colitis. It will be important to determine whether disease localization is comparable between southern and northern European centres. One possible factor that could account for the hypothetical northsouth axis could be that the diagnostic threshold in the south is higher, and the true incidence of IBD is underestimated.

The clinical data from six recent epidemiological studies of Crohn's disease are shown in Table 2. There are some variances in distribution of the three main localizations - ileocolonic,

\section{REFERENCES:}

1. Ekbom A, Helmick C, Zack M, Adami H-O. The epidemiology of inflammatory bowel disease: A large, population-based study in Sweden. Gastroenterology 1991;100:350-8.

2. Lindberg $\mathrm{E}$, Jarnerot $\mathrm{G}$. The incidence of Crohn's disease is not decreasing in Sweden. Scand J Gastroenterol 1991;26:495.500.

3. Haug K, Schrumpf E, Halvorsen JF, et al, and the Study Group of Inflammatory Bowel Disease in Western Norway. Scand J Gastroenterol 1989;24:1271-5.

4. Haug K, Schrumpf E, Barstad S, et al, and the Study Group of Inflammatory Bowel Disease in Western Norway. Scand J Gastroenterol 1988;23:517-22.

5. Langholz E, Munkholm P, Haagen Nielsen O, Kreiner S, Binder V. colonic and ileum. The increase in Crohn's disease incidence over the past 25 years in Denmark has been equally pronounced in all three areas. The proportion of cases presenting with high activity of disease has increased slightly over time, thus indicating not only increasing incidence but also more aggressive disease.

In the large Swedish study from Uppsala (1), it was proposed that birth cohorts of patients, born between 1945 and 1949 and between 1950 and 1954 had a higher incidence of both ulcerative colitis and Crohn's disease. Similar results were found by Hellers (12)

Incidence and prevalence of ulcerative colitis in Copenhagen County from 1962 to 1987. Scand J Gastroenterol 1991;26:1247-56.

6. Munkholm P, Langholz E, Haagen Nielsen O, Kreiner S, Binder V. Incidence and prevalence of Crohn's disease in the County of Copenhagen, 1962-87: A six fold increase in incidence. Scand ] Gastroenterol 1992;27:609-14.

7. Shivananda S, Pena AS, Nap M, et al. Epidemiology of Crohn's disease in the region of Leiden, The Netherlands. A study population from 1979 to 1983. Gastroenterology 1987;93:966-74.

8. Shivananda S, Peña AS, Mayberry JF, Ruitenberg EJ, Hoedemaeker PJ. Epidemiology of proctocolitis in the region of Leiden, The Netherlands. Scand J Gastroenterol 1987;22:993-1002. from Stockholm, whereas other studies have not been able to find such specifically exposed groups. The studies thus await further confirmation.

In conclusion, from the existing epidemiological data it appears that the two disease entities have remained practically unchanged during the past 20 years, as regards clinical appearance at diagnosis. The different pattern in incidence of ulcerative colitis and Crohn's disease support the concept of two different diseases. Finally, the steep increase in incidence of Crohn's disease points to an external factor in the etiology of the disease.

9. Trallori G, d'Albasio G, Palli D, et al. Epidemiology of inflammatory bowel disease over a 10 year period in Florence (1978 to 1987). Ital J Gastroenterol 1991;23:559-63.

10. Ranzi T, Campanini MC, Lisicandrano D, et al. Incidence of IBD in a defined area of Northern Italy: A four-year prospective study. (19901993). Ital J Gastroenterology 1991;23:603.

11. Sinclair TS, Brunt PW, Ashley N, Mowat G. Nonspecific proctocolitis in Northeastern Scotland: A community study. Gastroenterology 1983;85:1-11.

12. Hellers G. Crohn's disease in Stockholm County 1955-1974. A study of epidemiology, results of surgical treatment and long-term prognosis. Acta Chir Scand 1979;490 (Suppl):15-30 


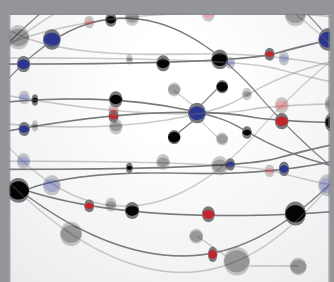

The Scientific World Journal
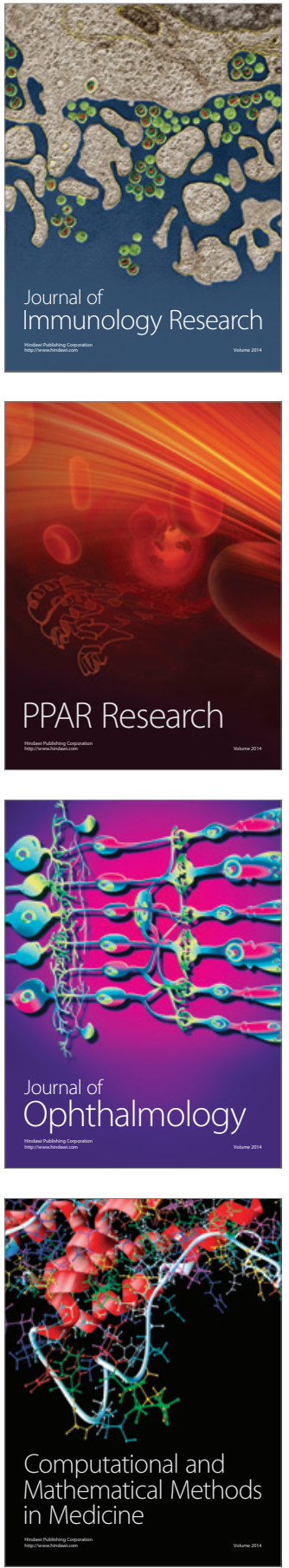

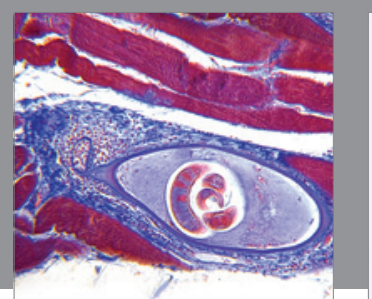

Gastroenterology Research and Practice

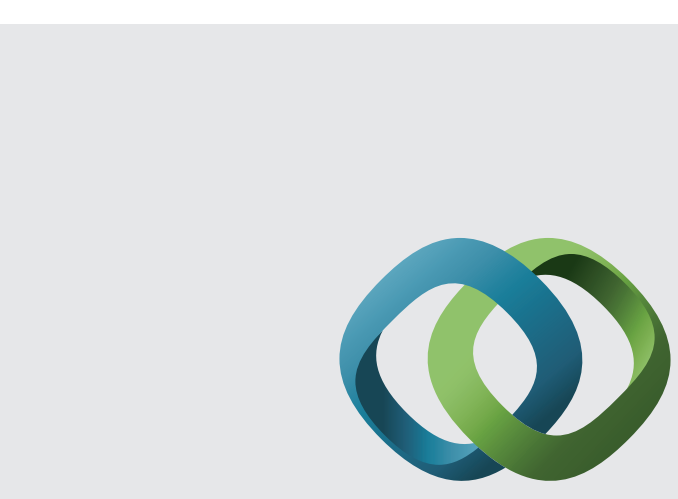

\section{Hindawi}

Submit your manuscripts at

http://www.hindawi.com
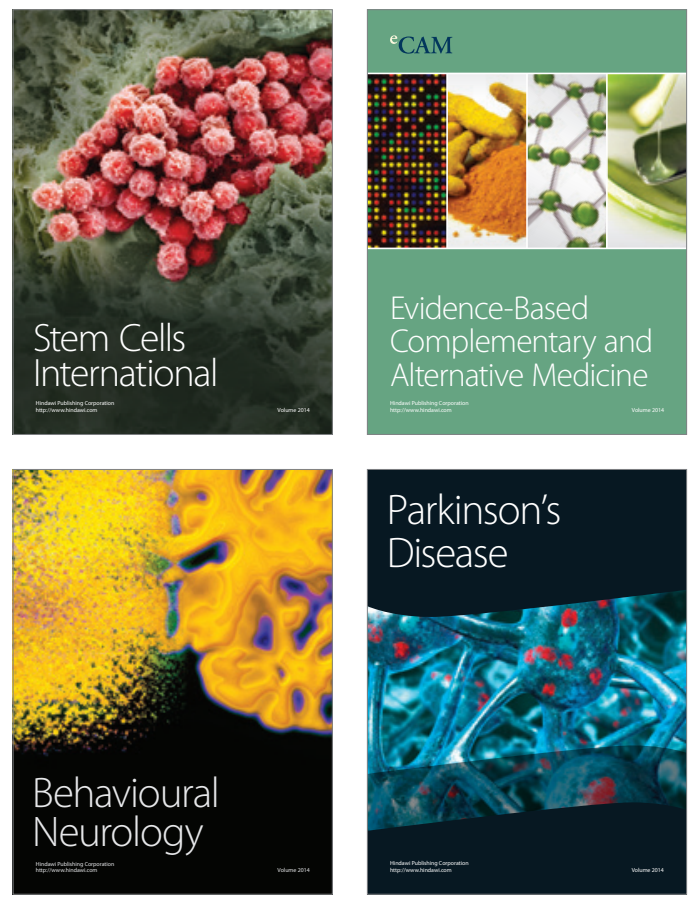
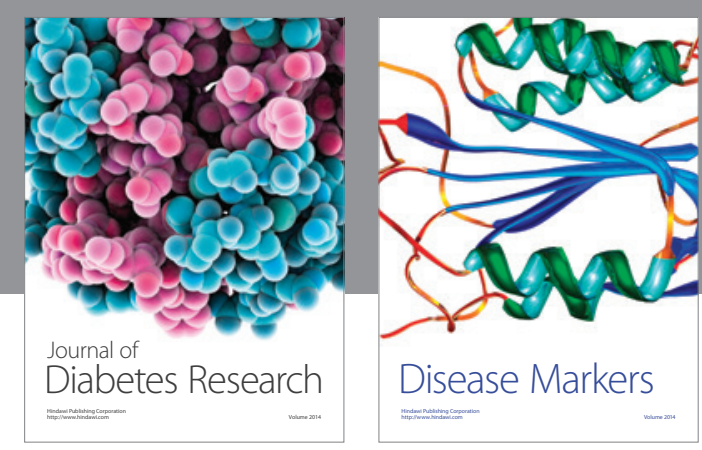

Disease Markers
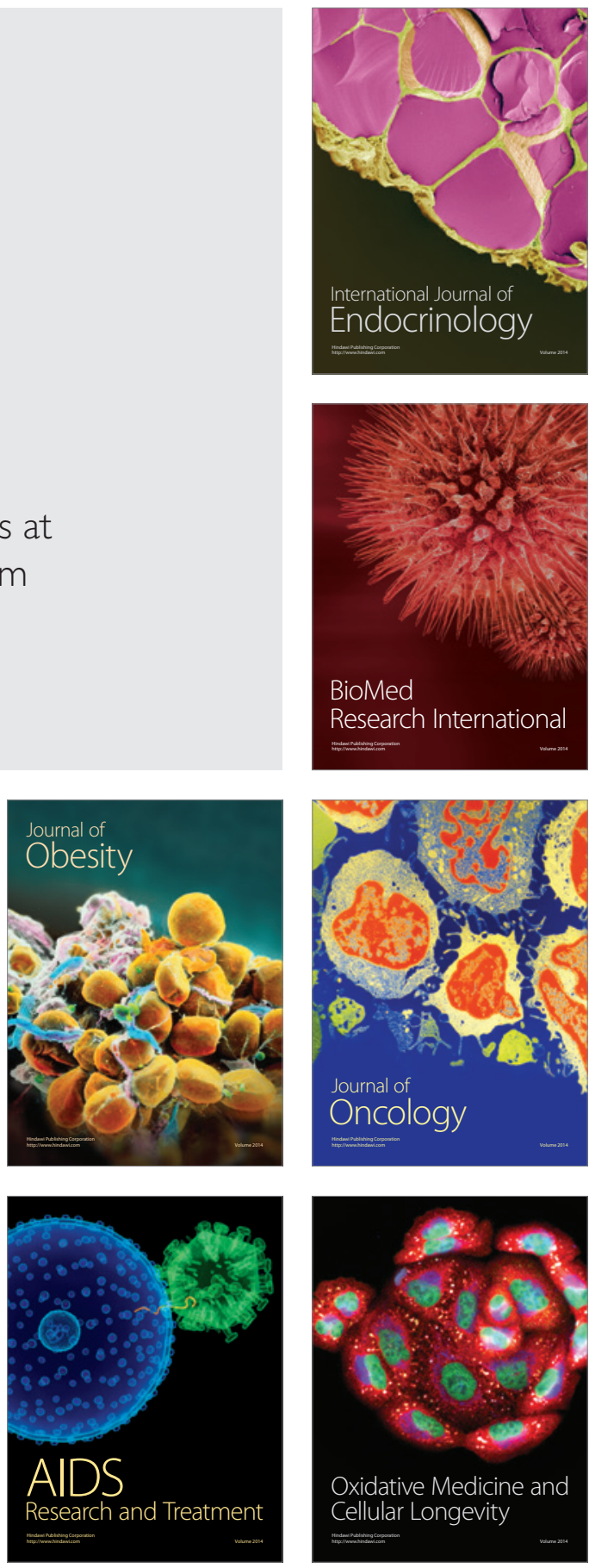